\title{
The hydrography of the North Sea. A review of our knowledge in relation to pollution problems
}

\author{
Arthur Lee and John Ramster \\ Fisheries Laboratory, Lowestoft, England
}

\begin{abstract}
KURZFASSUNG: Die Hydrographie der Nordsee. Ein Überblick über unsere Kenntnisse in Beziehung zu Problemen der Gewässerverunreinigung. Diese Einführung vermittelt einen Uberblick über die Entwicklung der verschiedenen Theorien über Diffusionsvorgänge im offenen Meer mit besonderer Beachtung der Nordsee. Die einzelnen Phasen in der Erarbeitung unserer Kenntnisse über das System der Restströme werden diskutiert. Ausführlich werden die Methoden, die für Strommessungen in verschiedenen Horizonten der Wasserkörper benutzt werden sowie ihre Anwendungsmöglichkeiten erörtert. Die Hauptrichtungen zukünftiger hydrographischer Arbeiten in der Nordsee werden skizziert.
\end{abstract}

\section{INTRODUCTION}

In order to predict how a pollutant will spread and travel in the sea it is necessary to have information about the dispersive processes present and the prevailing current systems. In this paper we attempt to review our present state of knowledge, or rather ignorance, in these two fields as far as the North Sea is concerned. We do not intend to deal with the situation with regard to the estuaries, bays and fjords around the North Sea; we are more concerned with the open sea itself.

\section{PROCESSES OF DISPERSAL}

In recent years oceanographers have been giving increasing attention to the problem of describing, as a function of space and time, the concentration of a substance that is dispersed in sea water by the combined effects of stirring, mixing and diffusion. Impetus to this study has been given by the development by Pritchard \& CARpenter. (1960) at the Chesapeake Bay Institute in the U.S.A. of the technique of using fluorescent dyes, like Rhodamine $B$, as tracers for use in experiments to determine these effects. Rhodamine $B$ can be detected in concentrations as low as 1 part in $10^{11}$ parts of sea water (i. e. $1 \mathrm{mg}$ per $100 \mathrm{~m}^{3}$ of water) by using a suitably modified Turner Model 111 fluorometer; this dye is relatively stable in sea water, is not affected greatly by light, and is relatively cheap to buy. It does have a serious disadvantage, however, in that it is adsorbed on to silt particles, and research is being carried on 
into the use of other dyes which do not have this defect. Alternatively it is possible to develop methods of correcting for such adsorption in the calculations of dispersal rates which follow from a particular experiment; this technique is being used by TALBOT \& HENRY (in press). Rhodamine B is carcinogenic, but as used in recent diffusion experiments there is no risk of harm to the operators. It might be thought to be harmful to marine life. Experiments reported by GeckLER \& WANDSTRAT (1964) showed that the clam, Mercenaria mercenaria, stained by internal adsorption of the dye at concentrations as low as 1 part in $4 \times 10^{6}$ parts of water, but that it was capable of clearing itself within a few days. Contact staining took place at concentrations of about 1 part in $10^{5}$ parts of water but no mortality was observed. WAUGH \& KEY (1967) have shown that the oyster, Ostrea edulis L., does not accumulate dye and become coloured when exposed to a Rhodamine $B$ concentration of 1 part in $7 \times 10^{7}$ parts of water for several days. At a concentration of 1 part in $10^{7}$ parts of water a faint coloration appears in about 16 minutes, and at twice this concentration contact staining occurs within 2 minutes. The oyster breaks down the dye in a relatively short time. Under field conditions there is a danger that commercial shellfish could become stained immediately after the dye is released, but they will rid themselves of it within 24 hours.

It is possible to follow a patch of Rhodamine $B$ for a number of days in the open sea if one uses the techniques developed by Joseph, Sendner \& WeIdemann (1964). For example, they were able to follow the patch resulting from the release of $350 \mathrm{~kg}$ of Rhodamine B in the eastern part of the central North Sea for a period of 114 hours; by that time the area with a concentration greater than 5 parts in $10^{11}$ was $24 \mathrm{~km}^{2}$, and the dye reached to $50 \mathrm{~m}$ depth. In August 1965 a release of $2000 \mathrm{~kg}$ was made in the same area in an international investigation carried out by the Federal Republic of Germany, the Netherlands and the United Kingdom under the auspices of the International Council for the Exploration of the Sea. The dye patch was followed for 560 hours ( 23 days 8 hours) and at that time the area with a concentration greater than 2 parts in $10^{11}$ was $1500 \mathrm{~km}^{2}$; again, the patch was confined to the water column above the thermocline. The results of this exercise, Operation RHENO as it is known, will be published by the International Council for the Exploration of the Sea in due course.

In 1958, JosepH \& SENDNER in the Federal Republic of Germany and Ozmidov in the U.S.S.R. published separate mathematical treatments of the problem of the spread of a substance in the sea from an instantaneous point source. Since that time further mathematical treatments have followed, but OKuвo (1962), at the Chesapeake Bay Institute, has now shown that the majority of them are based on particular cases of a more general partial differential equation.

Behind these treatments is the idea that eddy diffusion can be a function of both time and space. The dye experiments, such as Operation RHENO, are an attempt to verify them, but it must be noted that a number of assumptions are made: first that the dye is discharged in an infinite concentration along a line drawn vertically in the sea; second that the concentrations of diffused dye at all depths at a point in the patch are the same; third that only horizontal motions spread the dye; and fourth that although the patch may be carried along with the large-scale current, the dye is diffused radially from the centre of the patch in a way that depends on the distance 
from the centre. It is very doubtful indeed whether any of these assumptions is valid, and it should also be noted that the mathematical treatments give results applying only to the average of an ensemble of similar experiments. Verification of them by means of a few dye experiments must therefore be regarded with caution, particularly as there is no statistical procedure on which to base the comparison between the results of a particular experiment and the predicted average of the ensemble.

Although Rhodamine $B$ is relatively cheap to use, large-scale investigations based on it can be expensive. It is clear that repeated experiments on the scale of Operation RHENO are likely to be few. Furthermore, study of the experiments and theory to date is leading a number of workers to the view that measurements of current over a wide variety of time and space scales by means of moored buoy arrays are likely to be more rewarding. For example, BowDEN (1965) of Liverpool University has recently developed a theory which accounts for the spread of substances dissolved in the sea in terms of current shear throughout the water column, the vertical gradient of velocity combined with vertical turbulent mixing leading to an effective diffusion in the horizontal direction. This effect becomes more important if a moderate degree of stability is present, and it will be most noticeable in coastal areas. Its evaluation depends on knowing the mathematical form of the velocity profiles. For the North Sea the only comprehensive body of data which gives such profiles is that collected in the Straits of Dover and off the Dutch coast by VAN VEeN (1938). Later work by CARTWRIGHT (1961) has confirmed VAN VEEN's results in the Straits of Dover.

\section{ADVECTIVE PROCESSES}

We now turn to our knowledge of the current systems in the North Sea. As far as the tidal streams are concerned, those for the southern North Sea and the coastal areas off the British Isles, Belgium, the Netherlands, Germany and Denmark are well described in "Atlas der Gezeitenströme für die Nordsee, den Kanal und die Britischen Gewässer" published by the Deutsches Hydrographisches Institut, and those for the German Bight have been analysed in detail in a recent paper by Neumann \& Meier. (1964). The coverage of tidal stream observations in the central and northern North Sea is poor, however, and one would like to see the whole North Sea surveyed on the basis of an observation network like that used by Neumann \& MeIEr. When we come to consider residual currents, i. e. those that remain when tidal effects have been eliminated, our knowledge is even less good.

It was realized at the turn of the century that the only practical methods existing at that time of ascertaining the pattern of residual currents for the whole of the North Sea were firstly to release large numbers of drift bottles at regular intervals and draw inferences as to current speeds and direction from the pattern of recoveries, and secondly to deduce the current system from the surface salinity distribution of the region. BÖHNECKE (1922) showed that the routine measurements of surface salinity that had been taken over a 12-year period (1902 to 1914) could be used to produce quarterly charts of the distribution of salinity, and that from the spacing and form of the isohalines the general direction of water movement from area to area could be 
determined (Fig. 1). He felt that the movement of Atlantic water into the North Sea was the most important influence on the salinity distribution and hence on the residual drift through the region. Since his salinity maps showed that this inflow changed in character from quarter to quarter, so quarterly or "seasonal" changes in the circulation were found. Basically, however, he showed that throughout the year the Atlantic water moved (a) from the north of Scotland southwards down the east coast of Britain

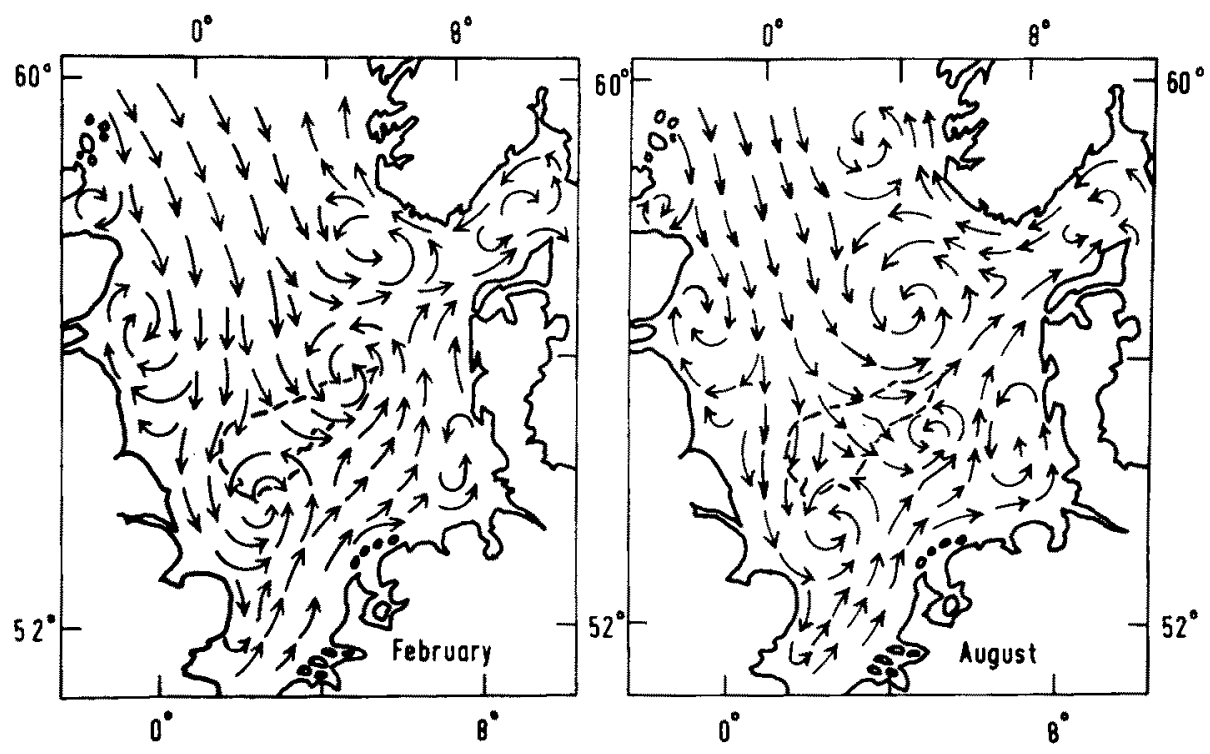

Fig. 1: Surface drift currents in the North Sea. (After BöHNEcke 1922)

to as far as Norfolk, (b) from the English Channel north-eastwards through the Southern Bight and into the German Bight. The merging of the two streams led to the formation, first, of the South West Dogger Bank Swirl in the area north of the Norfolk Banks and second, of the North East Dogger and Lindesnaes Swirls in the German Bight. North Sea water then moved into the Skagerrak and out of the region, together with water of Baltic origin, as a north-going Norway coast current.

This inferred pattern of residual surface circulation was corroborated to some extent for the southern North Sea by the work with surface drif bottles of CARRUTHERs (1925), though he placed more emphasis on the importance of changing seasonal wind systems to the pattern of residual surface drift than BöHNECKE (1922) had. Later, TAIT $(1930,1931,1937)$ suggested that the returns from the large-scale drift bottle releases in the northern North Sea, that had been undertaken at various times since 1900 , illustrated the existence of the two eddies inferred by BöHNECKE. The returns from releases by Carruthers (1926) of drift bottles which moved one or two feet above the sea-bed showed that, for the southern North Sea at least, the pattern of residual bottom currents had the same general characteristics as that of the surface, though speeds were lower, surface bottles moving at 5-12 n.mi. per day, depending on the area and month of release, whereas those at depth averaged only $1 \mathrm{n} . \mathrm{mi}$, per day. 
In 1960 the first large-scale releases of a plastic bottom drifter, the Woodhead seabed drifter, were made by our laboratory. By 1964 some 15000 of these had been released over networks of stations covering the whole of the southern North Sea, and with each release 50 per cent of the drifters were returned within 12 months, 80 per cent of these being caught by fishermen in their trawls. This rate of recapture was an improvement on that of both the surface and bottom bottles and it meant that a more detailed idea than hitherto could be gained of the pattern of bottom currents (Fig. 2). The basic components of the resulting map (RAMSTER 1965) are the west to east flow from the region of Flamborough Head and the movement north-eastwards from the

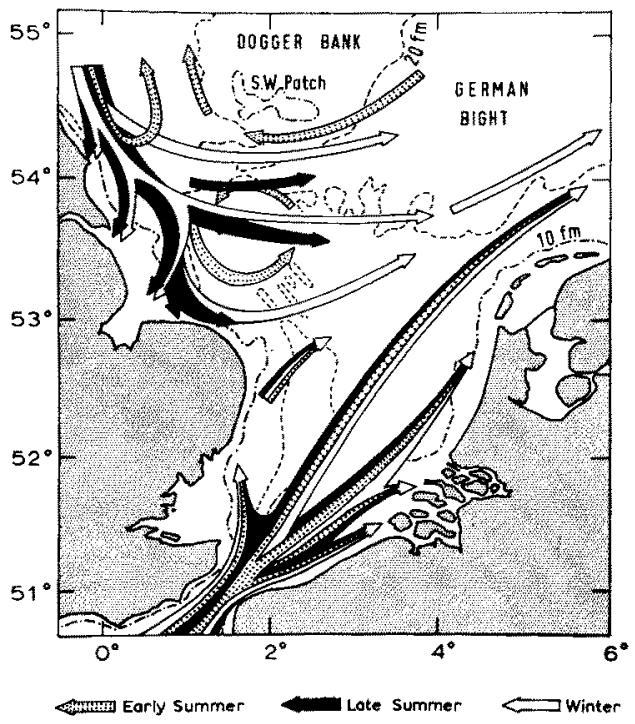

Fig. 2: The pattern of residual bottom currents in the southern North Sea in 1960 to 1961, as deduced from the returns of Woodhead seabed drifters

Straits of Dover, as suggested by BöHNECKE for the surface layers. Both lines of residual bottom drift give average speeds of 1 n.mi. per day. The seasonal fluctuations in strength and direction of flow in the area of South West Spit and Well Bank Flat, and the distinct lines of flow to the English coast, Bløden Ground and the coasts of Belgium, Holland and Germany, from well-nigh simultaneous releases in the Straits of Dover are the most interesting and novel results of the work. Subsequent releases in these areas have shown that the general trends of this map can be reproduced from year to year.

The idea that the pattern of residual currents of the North Sea changed seasonally is to be seen then in the maps of Böhnecke (1922), Carruthers $(1925,1926)$, TAIT $(1930 a, b, 1931,1937)$ and now in that produced from the returns of Woodhead seabed drifters. STEELE (1957) has used the data collected by TAIT for the Faroe-Shetlands Channel and the northern North Sea to show that the maximum inflow of Atlantic water to the North Sea occurs in the months September-February, and has suggested 
that by February-March each year this inflow is stopped at depth by a plug of cold North Sea water, so that for the next few months the volume of Atlantic water in the North Sea steadily diminishes. As the winds of the autumn break down the summer thermocline, the last vestige of this plug disappears and the yearly cycle begins again. It would seem likely therefore that, as BöHNECKE, TAIT and CARruTHERs all suggested at one time or another, the influence of the Atlantic is the dominating influence on the pattern of residual currents for the North Sea, and that we need to know the nature of the September-February inflow each year and the time of its cessation if we are to be able to tell from year to year whether or not there will be marked changes in the patterns of residual flow. However it will be appreciated that as yet we have only the simplest of ideas as to the pattern of residual currents of the southern North Sea.

Since there are indications though that the pattern of residual currents changes with depth we consider that it is worth-while to review our knowledge for the North Sea region of the currents in the different parts of the water column. Let us consider first the movement of the surface layer as this is relevant to the problem of oil pollution. This layer responds markedly to the wind stress and there is also an indirect effect of the wind, in that there is some mass transport due to the waves (Longuer HigGins 1953). The work of EKMAN (1905) and later of others, such as Durst (1924), suggests that there is a linear relationship, $u=k W$, between the wind speed $W$ and the surface current $u$. The factor $k$ is called the wind factor and represents a percentage rate, because $u$ is usually measured in $\mathrm{cm} / \mathrm{sec}$ and $W$ in $\mathrm{m} / \mathrm{sec}$. If we define $\mathrm{k}$ in this way, Ekman's relationship becomes $u=\frac{1.27 \mathrm{~W}}{\sqrt{\sin \varnothing}}$ where $\varnothing$ is the latitude. WIrTING (1909), using observations on Finnish lightships, suggested that at low wind speeds the relationship was of the form $\mathrm{u}=\mathrm{k}^{\prime} \sqrt{\mathrm{W}}$, but found a discontinuous change between Forces 3 and 4 Beaufort to a linear relationship. In a discussion of this paper Thorade (1914) shows that Wirting's data gives the equations $u=\frac{4.13 \sqrt{\mathrm{W}}}{\sqrt{\sin \varnothing}}$ at Forces $1-3$ and $u=\frac{1.60 \mathrm{~W}}{\sqrt{\sin ø}}$ at Forces $4-5$. Thorade, using navigational data from ships' logs for oceanic areas along extensive straight coasts where the permanent current at depth runs parallel to the coast, obtains the equations $u=\frac{2.59 \sqrt{\mathrm{W}}}{\sqrt{\sin \varnothing}}$ for winds up to Force 3 and $\mathrm{u}=\frac{1.26 \mathrm{~W}}{\sqrt{\sin \varnothing}}$ for winds above that. More recently LAWFORD \& Veley (1956), from a consideration of observations made with current meters at 4 to $5 \mathrm{~m}$ depth at lightvessels in the southern North Sea, conclude that the relationship is linear up to wind speeds of Force 3, and that it then changes to another linear relationship or becomes curved. MANDELBAUM $(1956,1958)$, on the other hand, on the basis of observations made with a ship $\log$ at the Amrum Bank Lightship concludes that the relationship is $u=2.7 V \bar{W}^{-}$up to wind speeds of Force 3 and that above that the relationship is $u=4.2 \mathrm{~W}$.

EKMAN's theory postulates that the surface wind-driven current should be at 
$45^{\circ}$ to the right of the wind in the northern hemisphere. This angle of deflection, $\alpha$, increases regularly with depth, so that eventually the current is in the opposite direction to the surface current; at the same time the current speed decreases regularly with depth. We thus have the well-known Ekman spiral. In shallow seas Exman's analysis leads to the result that the deflection at the surface is less than $45^{\circ}$, that it becomes smaller as the wind grows stronger, and that in very shallow water the currents flow in nearly the direction of the wind stress at all depths. In one of these papers (EKMAN 1906) and another much later (EKMAN 1928) the idea of a thin skin layer which moves in the direction of the wind stress is also developed. When we turn to the observational evidence concerning the value of $a$ we find that even for the deep ocean the meagre amount which is available is conflicting. As far as shallow seas are concerned, GAUL \& STEWART (1960) concluded that $\alpha=15^{\circ}$ to the right of the wind in the nearshore area off California, and WITrING (1909) found that in the Baltic Sea the deflection was to the right and that the angle can be expressed by the empirical formula $\alpha=34^{0}-7.5 \sqrt{\mathrm{V}}$. LisitzIN (1938) also found an average deflection to the right of the wind of $12^{\circ}$ at the Storbrotten Lightship in the Baltic Sea, and Hela (1952) showed that in the Gulf of Finland the deflection is to the right, that $\alpha$ decreases as the wind speed increases, and that characteristically it is about $20^{\circ}$. As far as the North Sea is concerned VELEY (1960), using the lightvessel observations in its southern part referred to above, found that the wind-induced current was nearly always to the right of the wind direction and that the angle of deflection was usually less than $20^{\circ}$. He also found that this angle changed with the direction of the wind owing to the influences of nearby coasts and banks.

Tomczak (1964) has described the drift of 8000 tons of crude oil pumped into the sea at the mouth of the Elbe estuary by a damaged tanker in January 1955. The patch was followed for 12 days as it moved northwards along the coast of SchleswigHolstein and it was found that it moved at a speed equal to about 4.3 per cent of the wind speed. In determining this percentage no allowance seems to have been made for the residual current on which the wind drift is superimposed. Along this stretch of coast it happens to run northwards and so it is possible that $\mathrm{k}$ was overestimated.

In all attempts to determine $\mathrm{k}$ by observations based on the travel of oil patches, drift envelopes and drift bottles there is this difficulty of isolating the direct effect of the wind stress from the residual current due to other causes; moreover the latitude term in Ekman's equation tends to be ignored. TomczaK (1964) describes a large-scale experiment in the North Sea carried out with double plastic drift envelopes of the type developed at the National Institute of Oceanography, Wormley. These envelopes float on the sea surface. Their drifts are compared with sets of trajectories computed from the wind speeds at $10 \mathrm{~m}$ height over the North Sea, as derived from weather maps for the periods when the cards were at liberty, and obtained by making $\mathrm{k}$ take 16 values between 1.5 and 5.5 , and by putting $\alpha=0$. The most favourable value was found to be $k=4.2$. This study was so large as to require the use of a computer, and assumed values for the residual current were introduced into the calculation of the trajectories over a zone close to the coasts of Germany, Denmark and Norway. They were not introduced elsewhere and there is therefore still some doubt about the certainty of the value of 4.2 for $\mathrm{k}$. The same doubt applies to the value $\mathrm{k}=3.3$ 
obtained by Hughes (1956) of Liverpool University from an experiment with the same type of drift card carried out by the National Institute of Oceanography in the eastern North Atlantic in 1954. Again no allowance was made for the residual current. Workers at the National Institute of Oceanography have, in fact, determined $\mathrm{k}$ with this type of envelope by direct measurements in reservoirs. For the wind at $10 \mathrm{~m}$ height they obtained $\mathrm{k}=3.3$ in light winds $(2 \mathrm{~m} / \mathrm{sec})$ and $\mathrm{k}=2.1$ in moderate winds $(8 \mathrm{~m} / \mathrm{sec}$ ) (Yeo 1957, and Charnock personal communication). It must be noted, however, that wave conditions in a reservoir are different from those in the sea and that this could affect the behaviour of the cards.

At various times the Fisheries Laboratory, Lowestoft has carried out experiments in the North Sea with drift envelopes, which have consisted of a single sheet of plastic. One such experiment was carried out in the Southern Bight in June 1952; envelopes
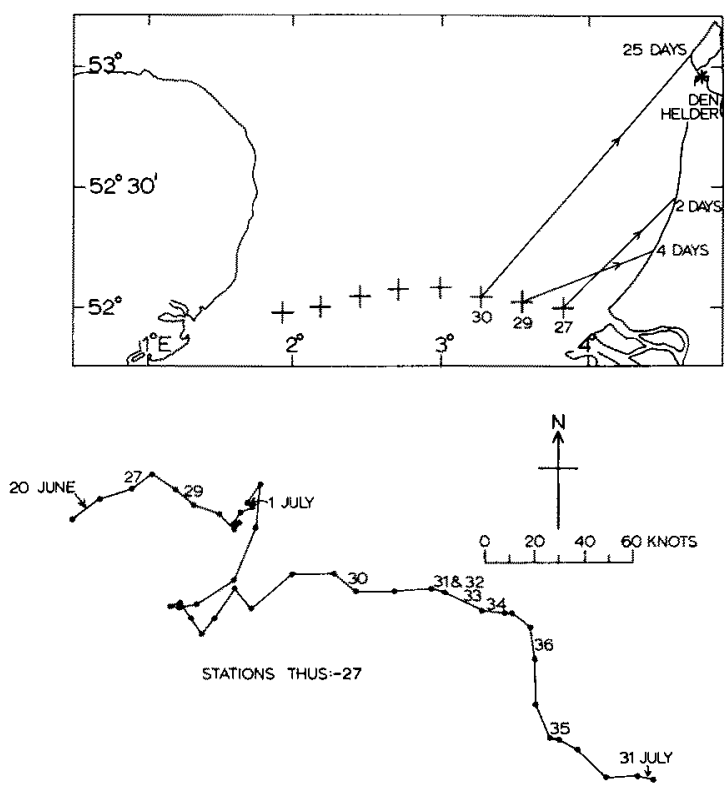

Fig. 3: Some results of drift envelope releases in the Southern Bight in June 1952, and the mean daily winds at Den Helder during the recovery period

were released at 8 positions between Harwich and the Hook of Holland, and the recovery positions for three of these stations are as shown in Figure 3. Envelopes from the station nearest the Dutch coast were recovered near Ijmuiden after two days, having covered $37 \mathrm{n} . \mathrm{mi}$. in that time, and envelopes from the next station further west were recovered further south on this coast after four days, having covered 33 miles. Some of the finders of these envelopes indicated the exact time at which they found them and so we have been able to get a more reliable estimate of the maximal time the envelopes could have been in the sea. The winds at Den Helder at the time are shown as a hodograph in Figure 3 and they are seen to be onshore. Using this hodograph and 
putting $\alpha=0$ we obtain $\mathrm{k}=4.6$ for envelopes from the station nearest the coast and $\mathrm{k}=3.5$ for the other. As the envelopes from the latter travelled more at right angles to the prevailing residual current, which flows northwards along the Dutch coast, the value of $\mathrm{k}=3.5$ is perhaps the better one. However, it can be seen that the winds did not cease to be onshore until after 13 days. If $k$ exceeded 2.6, then envelopes from the third station offshore should also have been stranded between the Hook of Holland and Ijmuiden after six days at liberty. None was recovered and, although this is no proof that none stranded, one is left in doubt as to the real value of $k$.

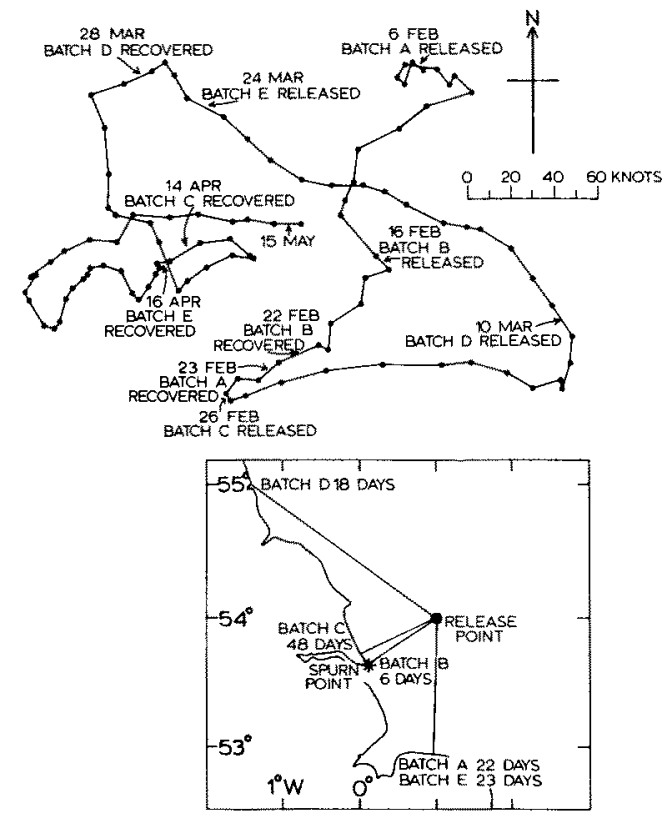

Fig. 4: Results of drift envelope releases of Flamborough Head, February-April 1956, and the daily mean winds at Spurn Head for the recovery period

In February-March 1956 another experiment was carried out on the Flamborough Off Ground. Five liberations of drift envelopes (Batches A-E) were made at different times, and the release points and the positions of recapture are shown in Figure 4. Of particular interest is Batch B: this moved in a south-westerly direction under a north-east wind and the first recaptures were made near Spurn Head after six days. Again the exact times of recovery of many of them are known, and a value of $\mathrm{k}=2.8$ has been obtained by using a wind hodograph for Spurn Head and putting $\alpha=0$. The influence of the residual current is thought to have been small in this case, as it is normally more or less at right angles to the track of the envelopes. Batches A and $\mathrm{E}$ stranded in the same place and were at liberty for the same number of days, namely 22 , but the former gives $k=1.7$ and the latter $k=3.4$. From Figure 4 it can be seen that Batch $A$ experienced north-west winds at first and then north-east, whilst Batch B experienced east and then north-north-west. Thus, Batch A most likely 
followed a track further offshore than Batch $\mathrm{E}$, and the difference in the values of $\mathrm{k}$ obtained can be explained by assuming that the residual current changed offshore; Batch A may have been opposed by the residual current and so gives a low $\mathrm{k}$ value, whilst Batch $\mathrm{E}$ may have been assisted by the current inshore and so gives a higher value.

The results of our laboratory's experiments with drift cards lead us to think that $\mathrm{k}$ lies between 2.0 and 3.5, but it is clear that this whole question is still very much open. Apart from the difficulty of eliminating residual current and isolating the direct wind effect, we must note that drift cards are of various types, so that different experiments are not likely to give the same results. There is also the possibility of the wind's moving the card itself, independently of the water. Some types can become partially clear of the water in rough seas and at these times they tend to sail before the wind: some observers have, in fact, seen drift cards carried through the air from wave crest to wave crest. Further, there is always the problem of knowing the exact time a card strands and so getting a reliable value of u. Finally, the exact nature of the relationship between wind and water speed is uncertain. Is it linear or parabolic? Does it change at some critical speed? Again, is movement of the surface skin layer directly downwind or not? There is evidently need for further experiment at sea, if we are to move into a position where we can predict the movement of, say, oil patches. Moored arrays of current meters can now give us the tidal streams and the residual currents. The tracking of small patches of oil or batches of drift cards in various wind and sea states could take place in the vicinity of such an array, and by comparing the current pattern given by this array with the tracks obtained one could get a better idea than now of the direct wind effect on the surface film.

The study of the movement of the uppermost $25 \mathrm{~cm}$ or so of the sea is equally troublesome. It has been mainly carried out with drift bottles, and the difficulties in interpreting the results obtained are well known. Even more doubt than before has been cast by the work of KARWOWSKI (1963) on the effect on drift bottle behaviour of the differing shapes, sizes and ballasting of the bottles used, and the fact that wave motion per se can account for some of the motion of drift bottles.

The weighted drift card designed to float upright in the water may be a better tool than the normal drift bottle. We do not know of its use in the North Sea, however. It has been used extensively off California and Тівву (1957) has analysed the paths of hundreds of such cards. These floated upright with $13 \mathrm{~cm}$ of their length below the surface and $5 \mathrm{~cm}$ above, and the wind is thought to have been ineffective in making them sail. The analysis resulted in a $\mathrm{k}$ value of 2.5 . STEvenson (1958) has used similar weighted cards in the same area and has had the advantage that a number of cards were recovered offshore. His calculated values of $\mathbf{u}$ are therefore more reliable than those of other workers. After making allowances for residual current, he concludes that in steady state conditions the upper $15 \mathrm{~cm}$ of the sea move more or less directly downwind at a velocity from 2 to 3 per cent of that of the wind.

An hitherto unpublished analysis carried out by us at Lowestoft of the results of an experiment executed in the southern North Sea as long ago as 1911 yields a comparable $\mathrm{k}$ value. Surface drift bottles, ballasted but not fitted with drags, were released at a number of stations in the Southern Bight in February and again in 
March. In the February experiment those released at stations near the Straits of Dover travelled north-east to the Netherlands under south-westerly winds; in the March experiments releases from these same stations travelled down the English Channel to the Cotentin peninsula under north-easterly winds. Using wind hodographs for Dover and putting $\alpha=0$, we obtain $k=2.3-2.8$ for the first experiment and $k=1.9$ for the second. The difference is due to the residual current through the Straits of Dover and it appears that $\mathrm{k}$ would have a value of 2.2 if there was no such current. It should be noted that no allowance for this sort of wind effect on the surface layer was made in the analysis of drift bottle data on which is based what has become the standard description of the circulation of the central and northern North Sea, namely that by TAIT (1937) discussed above.

Some experiments have depended on drift bottles fitted with drags at about $1 \mathrm{~m}$ depth. These bottles do not respond so readily to the effect of wind on the surface layer and carry out much longer journeys both in distance and time than the bottles without drags. In fact, they are so long that it is often impossible to draw any useful conclusions about them. For our knowledge of the currents at depths below $1 \mathrm{~m}$ in the North Sea we depend upon the valuable pioneering works carried out with current meters from lightvessels by Dr. J. N. CARRuTHERS and on the data obtained with moored recording current meters.

Carruthers $(1935,1949)$ made his observations at the Varne lightvessel at a depth of 4-5 m, firstly (1926 to 1937) with a CARruthers Drift Indicator and later (1938 to 1941,1950 to 1953 ) with his Vertical Log. It is difficult to overestimate the importance of the Varne measurements and the network of similar lightship measurements that sprang from them. By providing us with long-term current measurements (the Dutch and German schemes are running even now) they have given us indications, from at least a few points, of the way in which the residual current varies over the long-term period and its short-term links with changing wind systems. WYRTKI (1952), for example, took the monthly Varne wind and water residuals for the period 1926 to 1938 and showed that the water at 6 fathoms was moving at 2.9 per cent of the wind speed, and summarized diagrammatically in a particularly elegant way the links between the direction and speed of the wind and water for that period. LAWFORD \& VELEY (1956) used the same method for summarizing measurements at this point and elsewhere in the North Sea in the period 1950 to 1953. Their diagrams showed that the observed current can be seen to consist of wind-induced current and a permanent residual current. At Varne in the Straits of Dover, the tidal streams run reciprocally and the coastal configuration is such that winds from the north-east or south-west are likely to have the most effect; the residual current direction therefore varies little about the NE-SW line. At the lightressel $S 2$, in the open sea, winds from all directions have more or less the same effect and so the current isopleths become circular.

VELEY (loc. cit.) examined observations made at five lightvessels in the southern North Sea and eastern English Channel and showed that the permanent residual currents there corresponded to the basic North Sea circulation described above. Their speeds varied between 1.3 and $3.2 \mathrm{n}$.mi. per day. The wind-induced currents, which are added to the residual currents, had speeds ranging from 0.8 to 2.4 per cent 
of the wind speed. The coastal configuration and the submarine topography in the neighbourhood of each lightvessel influenced the wind-induced current and so caused the water speed/wind speed relationship to change according to the wind direction just as the angle of deflection of the wind-induced current changed, as has already been described above.

CARRUTHERS (1934) felt that the Varne measurements were illustrating the fact that the English Channel and the Straits of Dover acted as a "buffer zone" between the Atlantic water passing northwards along the west coast of Britain and the southerly sweep of that water into the North Sea. He felt that after a particularly strong inflow from the north, which resulted basically from changes in hemispherical

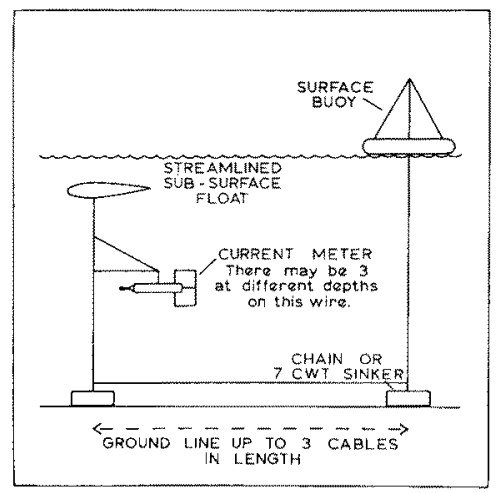

Fig. 5: A moored recording current meter station of the type laid by research vessels of the Fisheries Laboratory, Lowestoft

meteorology, currents at the Varne could be expected to weaken or change direction significantly. This they apparently did, but LuCAs \& RAE (1946) and WYRTKI (1952) disagreed. They suggested rather that at strong inflow times Atlantic water moves at greater volume than usual into the North Sea at both entrances, and that the changes in the long-term character of the current measurements at the Varne could be explained in other ways. This topic will be discussed in more detail in a forthcoming paper by Dickson (1967).

From the experience gained at the Varne there evolved a scheme whereby current measurements were taken regularly at many of the lightships moored along the coasts of the North Sea. During 1950-51 the results from these vessels were circulated by the International Council for the Exploration of the Sea as part of a series of monthly charts of wind conditions for the North Sea. If in these charts we read "water" for "wind" they provide the type of monthly chart we need to produce if we are to reach any real understanding of the circulation of the North Sea. As Carruthers (1930) said, "Put as a pure ideal we would like to be able to tell any enquirer what was the set of the currents in various parts of the North Sea on any occasion... Investigations of currents made on odd occasions may be of great interest certainly, but long series of records (1) set down in an easily applicable form, (2) resulting from carefully thought out schemes of work and (3) stretching without break over a long period of 


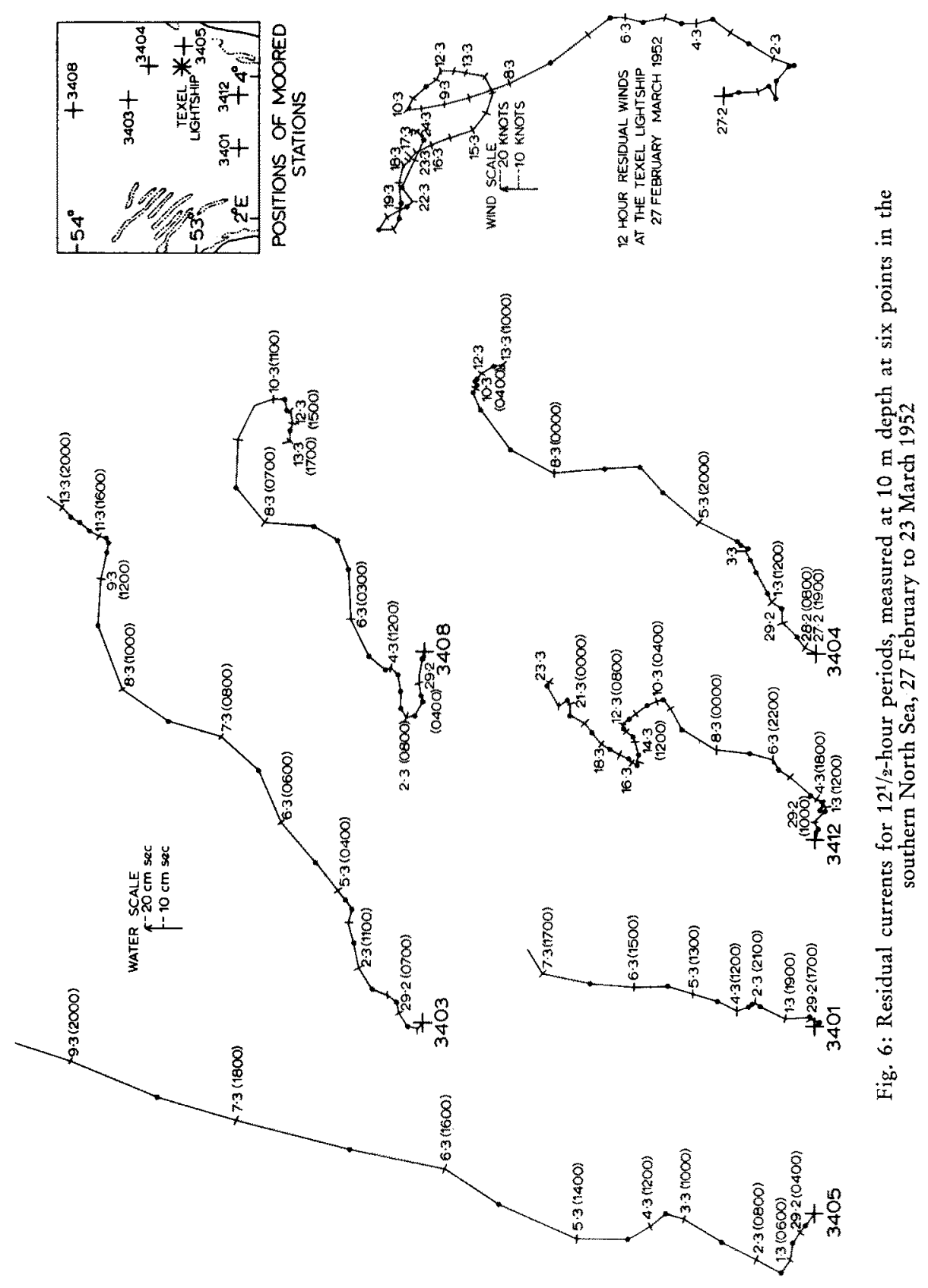



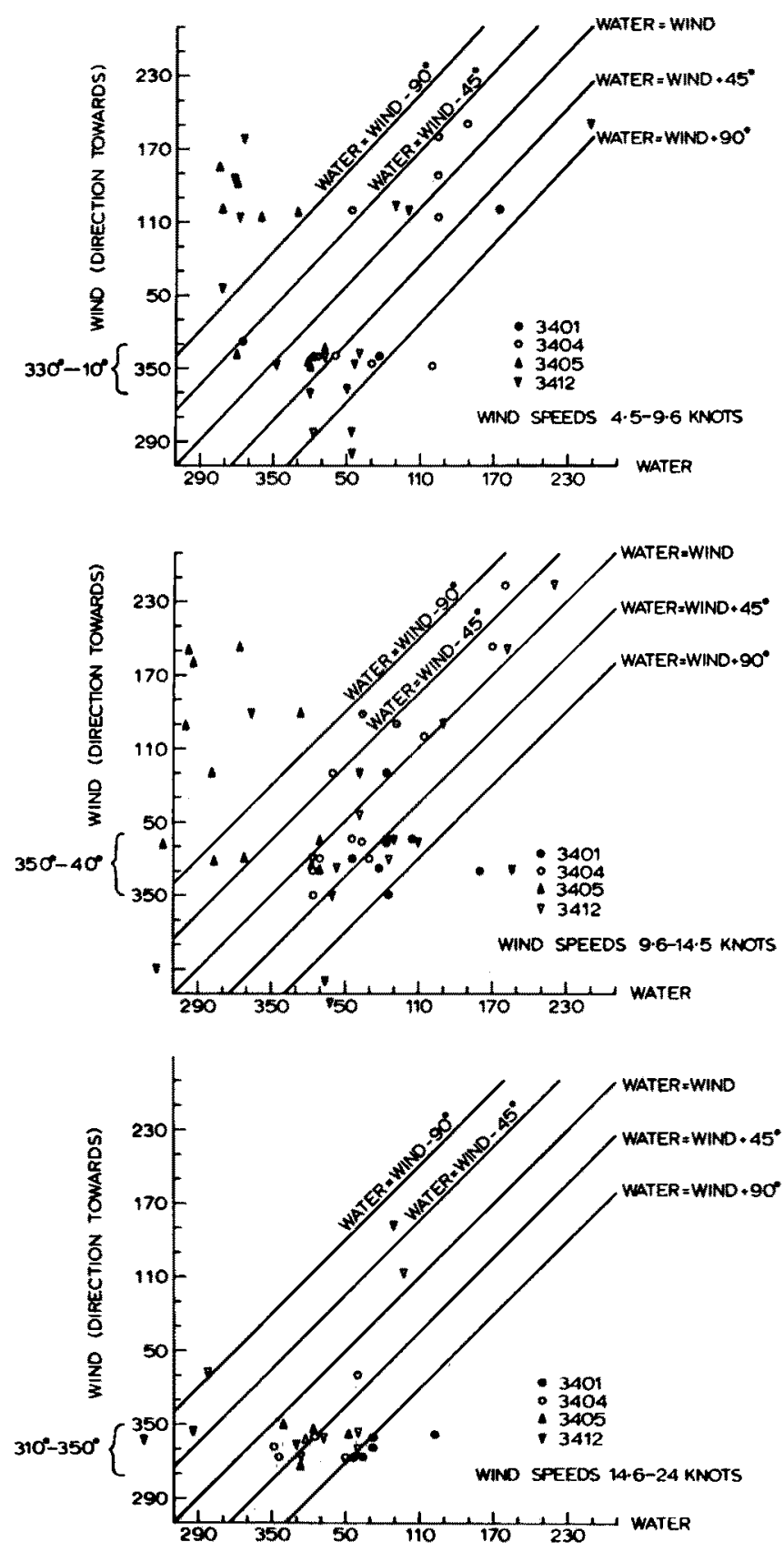

Fig. 7: The relationship, for various wind speeds, between the directions of 12-hour mean winds and 121/2-hour water residuals at four points in the southern North Sea, 27 February to 12 March 1952 


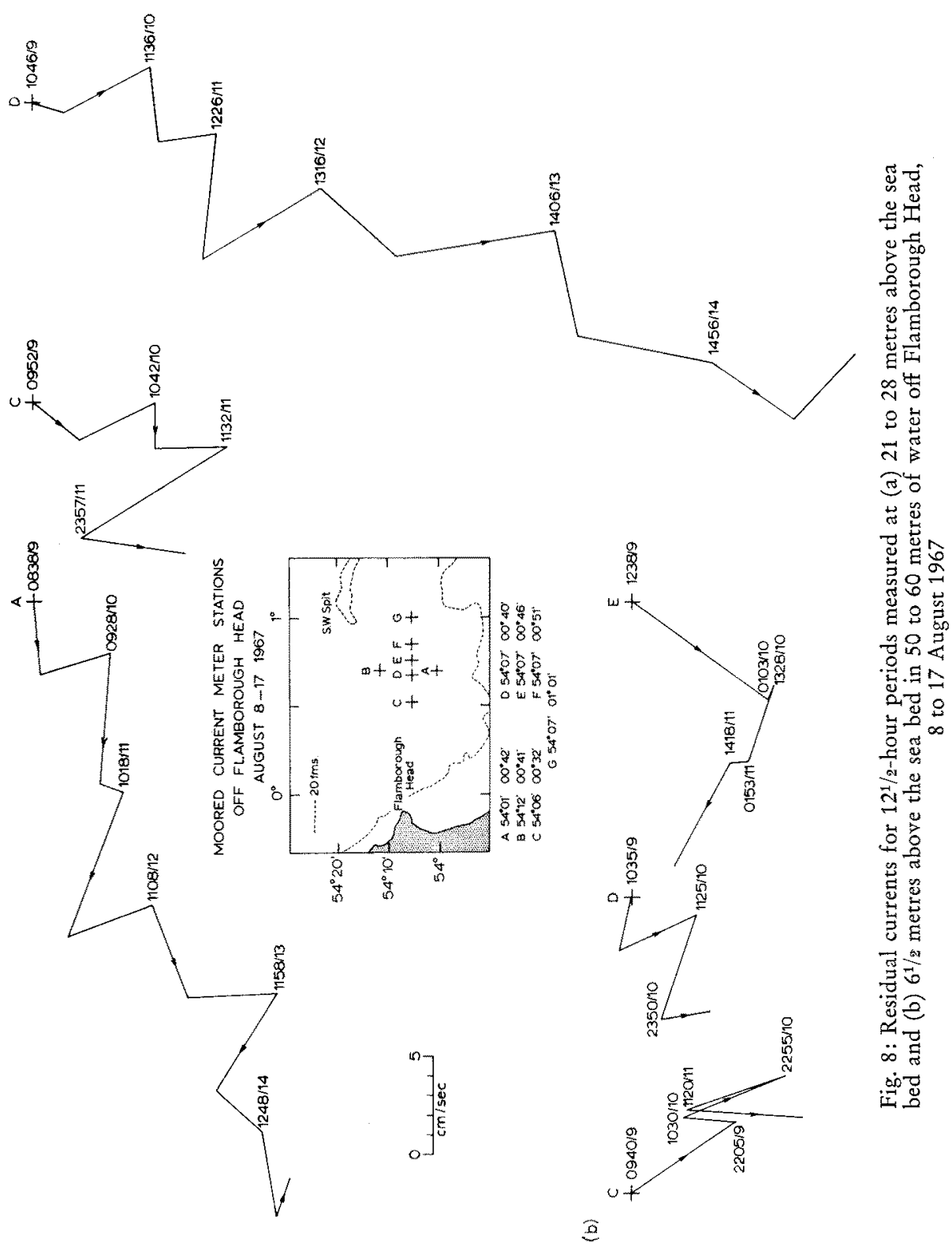


years - must be our main desiderata and such represent our aims." We feel that technology has at last caught up with these ideas and that it is now practical to think in terms of a network of moored current meter stations spread over the North Sea and providing data over the long term.

The type of station envisaged has a surface buoy, wires leading to anchors, and a wire carrying the actual current-meters (Fig. 5). As early as 1950 the Deutsches Hydrographisches Institut was using meters which recorded current velocity and direction every five minutes on ciné-film for up to 28 days at a time in the southern
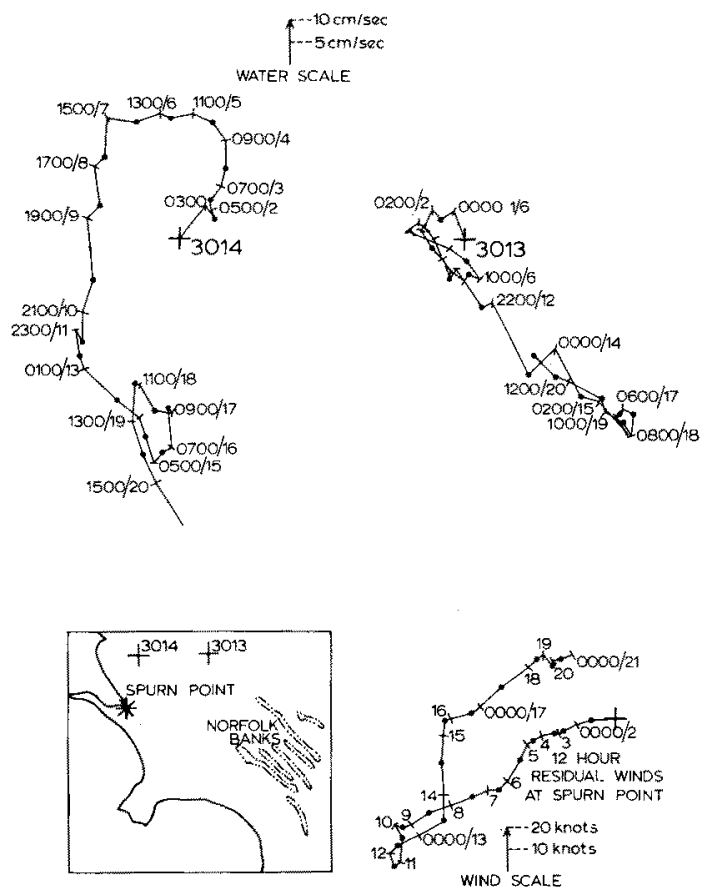

Fig. 9: Residual currents for $12^{1 / 2}$-hour periods measured at $10 \mathrm{~m}$ depth at two stations off the coast of Holderness (31 May to 21 June 1951)

North Sea. We have taken the published data (Deutsches Hydrographisches Institut 1958) for the period 1950 to 1955 and computed 121/2 hour residuals from them. We find, for example, that of the stations occupied in early March 1952 for a fortnight or so at a depth of $10 \mathrm{~m}$ (Fig. 6) four points in the Southern Bight showed very similar residual trends. A little further north the expected "easting" of the residuals occurred and this change of general trend was apparently independent of the winds blowing over the area. Furthermore, comparison of the sets of data for the four southerly stations with the 12-hourly mean winds measured at the Texel and Goerée lightships shows that their relationship with the wind was independent of wind speed (Fig. 7). When directions of wind and water movement are compared for wind strengths lying between 4 and 24 knots, then the only semblance of order appears when the 
wind direction is towards the sector $310^{\circ}-40^{\circ}$. At such times the water residuals tend to lie at about $45^{\circ}$ to the right of the wind.

Because we feel that only moored recording current meter stations can provide us with such detailed residual current systems, we have been devoting a considerable effort in the last few years to developing a moored instrument array for use in the North Sea, English Channel and Irish Sea. It is based on the Plessey-UK current meter described by Hodges (1967), which is itself derived from that developed at the Christians Michelsen Institute, Bergen by AanderaA (1964). The Plessey-UK meter is capable of recording current speed and direction and temperature at 10-minute intervals for periods of up to 80 days, and the observations are recorded on magnetic tape so that the data can be processed by means of a computer. The problems of developing this array so as to obtain meaningful data have proved to be considerable and we do not pretend to have solved them all as yet. We are aware that we still cannot record the currents in the boundary layers at both ends of the water column. The Plessey-UK meter is not of suitable dimensions for use closer than $4 \mathrm{~m}$ to the sea-bed and we have not yet devised a wave-cheating rig that prevents the waves from falsifying the recordings at depths less than $8 \mathrm{~m}$ below the surface. As far as the North Sea is concerned, our only major exercise to date has been conducted between Flamborough Head and the western edge of the Dogger Bank.

Its purpose was to ascertain how representative of an area are the recordings made at a single moored station. As yet only preliminary results from some of the stations are available but these show marked differences of trend from point to point (Fig. 8). Two stations occupied in 1951 by the Deutsches Hydrographisches Institut to the south of this region were 20 n.mi. apart and the residual currents obtained showed little or no correspondence from day to day (Fig. 9).

\section{CONCLUSION}

We hope it will be readily appreciated from this review that there is a need to measure currents at a variety of depths and in various time and space scales if we are to acquire that knowledge of the North Sea which is necessary to attack the problems of marine pollution. The moored current meter array is essential for further studies of those processes that disperse substances in solution in the sea and of those that transport oily substances laid on the sea surface and material dumped on the sea-bed. It is also essential if we are to understand the underlying residual currents that transport all of the pollutants. As yet, for example, we have virtually no current measure-ments at all north of the Dogger Bank in what is, in effect, the most important part of the residual sweep of water through the region. Until the envisaged network exists, and has existed for several years, we shall not understand the circulation of the North Sea and the mechanism that drives it.

Although it is true that it is possible to construct mathematical models of the circulation similar to those used in storm surge research for predicting tidal heights, it is impossible to verify those models without observations at sea. Again, as an aid to pollution studies one can derive elementary estimates of the budget of the North 
Sea on the basis of our present crude knowledge, as has been done by WALlauscheK \& LüTZEN (1963), but to improve on these and to give them any certainty at all we need actual measurements of the inflows and outflows.

If we physical oceanographers are going to make a significant contribution to pollution problems we must be able to predict what will happen to a pollutant should it be discharged into the sea. We can make such predictions only if our oceanographical theory is adequate. To ensure that it is adequate we must obtain much more observational and experimental data at sea.

\section{SUMMARY}

1. The development of the various theories of diffusion processes in the open sea are reviewed with particular reference to work in the North Sea.

2. The stages by which our present knowledge of the residual current system of the region has been built up are discussed.

3. A detailed discussion follows of the methods by which current measurements of one kind or another have been made at various points in the water column and the use to which these measurements have been put.

4. An outline is given of the way in which we feel future work in this field must develop.

\section{LITERATURE CITED}

AanderaA, I., 1964. A recording and telemetering instrument. NATO Subcomm. oceanogr. Res. 16, Tech. Rep.

BöHNecke, G., 1922. Salzgehalt und Strömungen der Nordsee. Veröff. Inst. Meeresk. Univ. Berl., N. F., A. Geogr.-naturwiss. R. H. 10, 1-34.

BowDEN, K. F., 1965. Horizontal mixing in the sea due to a shearing current. J. Fluid Mech. 21, 83-95.

Carruthers, J. N., 1925. The water movements in the southern North Sea. Part 1. The surface drift. Fishery Invest., Lond. (Ser. 2) 8 (2), 1-119.

- 1926. The water movements in the southern North Sea. $\mathrm{Pt}$. The bottom currents. Fishery Invest., Lond. (Ser. 2) 9 (3), 1-114.

- 1930. Aims and methods in the study of currents. Rapp. P.-v. Réun. Cons. perm. int. Explor. Mer 64, 24-32.

- 1934. Certain fishery applications of the results of researches on marine currents carried out from the Lowestoft Fisheries Laboratory. Rep. Br. Ass. Advmt Sci. (Sect. D) 104, $325-327$.

- 1935. The flow of water through the Straits of Dover as gauged by continuous currentmeter observations at the Varne Lightvessel $\left(50^{\circ} 56^{\prime} \mathrm{N}-1^{\circ} 17^{\prime} \mathrm{E}\right)$. Part II. Second report on results obtained. Fishery Invest., Lond. (Ser. 2) 14 (4), 1-67.

- Lawford, A. L. \& Veley, V. F. C., 1949. Studies of water movements and winds at various lightvessels in 1938, 39 and 40. The Varne Lightship and her successors. Annls Biol. 6, 115-120.

CARTwright, D. E., 1961. A study of currents in the Strait of Dover. J. Inst. Navig. 14, 130-151.

Deutsches Hydrographisches Institut, 1958. Strombeobachtungen in der südwestlichen Nordsee in den Jahren 1951-55. Meeresk. Beob. Ergebn. dt. hydrogr. Inst. 9. 
Dickson, R. R., 1967. Long-term changes in the hydrography of the European shelf seas since 1905, and the effects of these upon the distribution and abundance of various marine organisms. (Ph. D, thesis submitted to University of East Anglia, September 1967.)

Durst, C. S., 1924. The relationship between current and wind. Q. Il R. met. Soc. 50, $113-119$.

Ekman, V. W., 1905. On the influence of the earth's rotation on ocean currents. Ark. Mat. Astr. Fys. 2, 1-52.

- 1906. Beiträge zur Theorie der Meeresströmungen. Annln Hydrogr. Berl. 34, $423 \mathrm{ff.}$

- 1928. Eddy viscosity and skin friction in the dynamics of wind and ocean-currents. Mem. R. met. Soc. 2 (20), 161-172.

Gaul, R. D. \& Stewart, H. B., 1960. Nearshore ocean currents off San Diego, California. J. geophys. Res. 65, 1543-1556.

GeCKLER, J. R. \& Wandstrat, T. A., 1964. Uptake and retention of Rhodamine B by quahog clams, Mercenaria mercenaria. Chesapeake Sci. 5, 134-137.

HeLA, I., 1952. Drift currents and permanent flow. Commentat, physico-math. 16 (14), 1-28.

Hodges, G. F., 1967. The engineering for production of a recording current meter. Int. bydrogr. Rev. 44 (2), 151-167.

Hughes, $P, 1956$. A determination of the relation between wind and sea-surface drift. Q. Jl R. met. Soc. 82, 494-502.

Joseph, J. \& SENDNER, H., 1958. Uber die horizontale Diffusion im Meere. Dt. bydrogr. Z. $11,49-77$.

- - \& Weidemann, H., 1964. Untersuchungen über die horizontale Diffusion in der Nordsee. Dt. bydrogr. Z. 17, 57-75.

KaRWOWSKI, J., 1963. Measurement of the sea currents by means of drift bottles. Int. bydrogr. Rev. 40 (2), 119-123.

Koppen, A., 1898. Aus Arch. dt. Seew. 21 (5).

LAwFORd, A. L. \& Velex, V. F. C., 1956. Change in the relationship between wind and surface water movement at higher wind speeds. Trans. Am. geophys. Un. 37, 691-693.

Lisitzrn, E., 1938. Uber den Zusammenhang zwischen Wind und Strom bei dem Feuerschiff Storbrotten im nördlichen Âlandsmeer. J. Cons. perm. int. Explor. Mer 13, 293-303.

Longuet-Higains, M. S., 1953. Mass transport in water waves. Pbil. Trans. R. Soc. (Ser. A.) 246, 535-581.

LucAs, C. E. \& RaE, K. M., 1946. The plankton of the North Sea in relation to its environment. Pt 1. The hydrological background in the southern North Sea, 1930-37. Hull Bull. mar. Ecol. 3, 1-33.

Mandelbaum, H., 1956. Evidence for a critical wind velocity for air-sea boundary processes. Trans. Am, geophys. Un. 37, 685-690.

- LAWFORd, A. L. \& Veley, V. F. C., 1958. Discussion of "Evidence for a critical wind velocity for air-sea boundary processes" and "Change in the relationship between wind and surface water movement at higher speeds". Trans. Am. geophys. Un. 39, 335-336.

Neumann, H. \& Meier, C., 1964. Die Oberflächenströme in der Deutschen Bucht. Dt. hydrogr. Z. 17, 1-40.

Oxubo, A., 1962. A review of theoretical models of turbulent diffusion in the sea. Tech. Rep. Chesapeake Bay Inst. 30 (Ref. 69-29).

Ozmmov, R. V., 1958. On the circulation of horizontal diffusion of the pollutant patches in the sea. Dokl. Akad. Nank SSSR. 120, 761-763.

Pritchard, D. W. \& Carpenter, J. H., 1960. Measurement of turbulent diffusion in estuarine and inshore waters. Bull. int. Ass. scient. Hydrol. 20,37-50.

Ramster, J. W., 1965. Studies with the Woodhead Sea-bed Drifter in the southern North Sea. Lab. Leafl. Fish. Lab. Lowestoft (N.S.) 6, 1-4.

STEELE, J. H., 1957. The role of lateral eddy diffusion in the northern North Sea. J. Cons. perm. int. Explor. Mer 22, 152-162.

StEvenson, R. E., 1958. An investigation of nearshore ocean currents at Newport Beach, California. (Mimeogr. Rep.) 
TAIT, J. B., 1930. The surface water drift in the northern and middle areas of the North Sea and in the Faroe-Shetland Channel. Pt 1. A preliminary report upon the results of Scottish experiments with surface-floating bottles, 1910-1914. Scient. Invest. Fishery Bd Scotl. 2, 1-82.

- 1930. The surface water drift in the northern and middle areas of the North Sea and in the Faroe-Shetland Channel. Pt 2 (Sect. 1). A cartographical analysis of the results of Scottish surface drift-bottle experiments commenced in the year 1910. Scient. Invest. Fishery Bd Scotl. 4, 1-56.

- 1931. The surface water drift in the northern and middle areas of the North Sea and in the Faroe-Shetland Channel. Pt 2 (Sect. 2). A cartographical analysis of the results of Scottish surface drift-bottle experiments commenced in the year 1911. Scient. Invest. Fishery Bd Scotl. 3, 1-88.

- 1937. The surface water drift in the northern and middle areas of the North Sea and in the Faroe-Shetland Channel. Scient. Invest. Fishery Bd Scotl. 1, 1-66.

Talbot, J. W. \& Henry, J. L., 1968. The adsorption of rhodamine-B on to materials carried in suspension by inshore waters. J. Cons. perm. int. Explor. Mer 31 (3) (in press).

Thorade, H., 1914. Die Geschwindigkeit von Triftströmungen und die Ekmansche Theorie. Annln Hydrogr. Berl. 42, 379-391.

Trвby, R. B., 1957. A study of currents in Santa Monica Bay by the use of drift cards. (Unpublished manuscript quoted by STEVENSON 1958).

Tomczax, G., 1964. Investigations with drift cards to determine the influence of the wind on surface currents. In: Studies on oceanography. Ed. by K. Yoshida. University of Tokyo Press, 129-139.

VeEn, J. van, 1938. Water movements in the Straits of Dover. J. Cons. perm. int. Explor. Mer 13, 7-36.

VELEY, V. F. C., 1960. The relationship between local wind and water movement in coastal waters of the British Isles. In: Proceedings of the 1st International Conference on waste disposal in the marine environment. Ed. by E. A. Pearson. Pergamon Press, Oxford, 285-295.

Wallauschek, E. \& Lutzen, J., 1963. Study of problems relating to radioactive waste disposal into the North Sea. 1. Oceanographical and biological conditions in the North Sea. Organization for Economic Cooperation and Development, European Nuclear Energy Agency, $51 \mathrm{pp}$.

WAUGH, G. D. \& KEY, D., 1967. Experiments with Rhodamine B and European flat oysters (Ostrea edulis L.). J. Cons. perm. int. Explor. Mer 31, 272-278.

Wirting, R., 1909. Zur Kenntnis des vom Winde erzeugten Oberflächenstromes. Annln Hydrogr. Berl. 37, 193-203.

WyrtKx, K., 1952. Der Einfluß des Windes auf die Wasserbewegungen durch die Straße von Dover. Dt. bydrogr. Z. 5, 21-27.

YEO, S.-A., 1957. The problem of wind drift near a free water surface. Bull. Challenger Soc. $3(9), 35$. 